\title{
European welfare states: does decentralization affect poverty?
}

\begin{abstract}
The shifting of welfare systems to the local level may have positive or negative consequences. On the one hand, decentralization is expected to better tailor welfare policies to the population specific needs; on the other hand, especially in the presence of weak supervision by the central government, it may cause inequalities and territorial fragmentation. The main objective of the paper is to explore the relationship between welfare state typologies - with different degree of decentralization - and the level of monetary poverty and material deprivation of citizens. Using data from official statistics, we model individual binary outcomes (living or not under the poverty line, being or not able to make ends meet) as a function of both family-level and countrylevel characteristics. The empirical analysis is run on a selection of European countries for the year 2013.
\end{abstract}

Keywords Welfare systems · Poverty · Decentralization measures · Social protection statistics

\section{Introduction}

The decentralization of responsibilities to increasingly lower levels of government may have positive or negative consequences. On the one hand, decentralization is expected to better tailor welfare policies to the population specific needs; on the other hand, especially in the presence of weak supervision by the central government, it may lead to negative implications like territorial fragmentation and inequalities $([22],[6])$.

According to some scholars, effectiveness of decentralization depends on the national welfare framework and especially on the form of the welfare state. For example, J. M. Sellers and A. Lidstrm in [24] argue that a strong territorial decentralization is essential for a public welfare state built around universalist 
egalitarian ends (or Social Democratic welfare state, see [12]), since it allows for assuring equal provision regardless of the place.

This study explores the relationship between welfare states typologies with different degrees of decentralization - and poverty. We consider several aspects of welfare systems such as the amount of resources devoted to social protection, the rules for accessing benefits (whether means-tested or not), the origin of social protection funding (if public or private), the different mix of economic transactions performed (benefit in cash or benefits in kind) and, finally, their level of decentralization. Data are taken from Eurostat and Oecd databases.

We report the results of a statistical analysis aimed at assessing whether the decentralization of welfare systems is a significant predictor of poverty. To this end, we estimate pooled logistic regressions for a sample of 127324 households selected in 14 European countries. The paper is organized as follows. Section 2 is devoted to a synthetic description of European official statistics relating social protection. Section 3 describes variables and indicators used in the empirical analysis, section 4 sets out the methodology adopted and presents main results. Finally, section 5 provides commentary on the results in terms of their strengths and weaknesses.

\section{European official statistics on social protection}

Eurostat and Oecd supply internationally harmonized statistics on social protection receipts and expenditures through two thematic databases: the Esspros (European System of Integrated Social Protection Statistics) and the Socx (Social expenditure ) databases.

Esspros is an accounting framework developed in the late 1970s by Eurostat and the EU member states to allow international comparison among administrative national data on social protection ([13]). Here, social protection is defined as encompassing "all interventions from public or private bodies directed to relieve households and individuals of the burden of a defined set of risks and needs, provided that there is neither a simultaneous reciprocal nor an individual arrangement involved" ([13], pag. 9). The categories of risks and needs covered are eight, namely: sickness/health care, disability, old age, survivors, family/children, unemployment, housing, social exclusion not elsewhere classified. Esspros is composed of the core system and of modules. The core system records the accounting of social protection schemes distinguishing receipts (origin of financing) from expenditures (uses of financing). The modules contain supplementary statistical information on particular aspects of social protection, namely pensions' beneficiaries and net social benefits. Receipts are analysed according to the nature of the payment (social contribution, general government contributions, transfers from other schemes and other receipts) but also according to the paying sector (e.g. whether central or local government). On the expenditure side, social benefits are analysed by function (i.e. 
the risk or need covered) and by type (if in cash or in kind, if means-tested or not).

In the 1990s, Oecd developed a database called Socx (Social expenditure database) for monitoring trends in aggregate social expenditure and analysing changes in its composition, across Oecd countries. Oecd defines social expenditures as "the provision by public and private institutions of benefits to, and financial contributions targeted at, households and individuals in order to provide support during circumstances which adversely affect their welfare, provided that the provision of the benefits and financial contributions constitutes neither a direct payment for a particular good or service nor an individual contract or transfer" ([3] p. 90). Oecd distinguishes nine social different policy areas, which only approximately correspond to the risks/needs specified by Esspros: old age, survivors, incapacity-related benefits, health, family, active labour market programmes, unemployment, housing, and other social policy areas. Like Esspros, the Socx database analyses social benefits by function and by type. Furthermore, it allows one to separate public from private benefits. Social benefits are classified as public when general government (central, state/local governments, social security funds) controls the relevant financial flows. Conversely, all social benefits not provided by general government are considered as private.

Eurostat disseminates statistics on social protection accounting also within National Accounts (NAs). According to the ESA 2010 definition "Social benefits are transfers to households, in cash or in kind, intended to relieve them from the financial burden of a number of risk or needs, made through collectively organized schemes, or outside such schemes by government units and NPISHs; they include payments from general government to producers which individually benefit households and which are made in the context of social risks or needs" ([14] 4.83). The risks or needs covered are the following: sickness, invalidity/disability, occupational accident or disease, old age, survivors, maternity, family, promotion of employment, unemployment, housing, education, general neediness ([14]4.84). It is worth noting that NAs include education within the boundaries of social protection, which, at the opposite, is excluded both by Esspros and by Socx. With respect to the other data sources, NAs supply estimates of social benefits at sub-national level, more precisely by Nuts 2 regions ([15]). This data is currently published by Eurostat, within the Households regional accounts.

National statistical offices disseminate micro data on the supply and use of social protection services. However, these statistics seldom permit sound comparisons among countries. Eusilc (EU Statistics on Income and Living conditions) represents an exception, providing internationally comparable details on cash social benefits received by households and individuals. Although Eusilc definition of social benefits is based on Esspros concepts, some differences are present: Eusilc social benefits include education and covers current transfers only; furthermore, they do not include in kind benefits with the only exception of housing. 
The above described data sources allow us to obtain a complete and detailed picture of social protection supply and demand at the country level ([10]). Welfare systems can be compared by looking at several aspects suggested in literature $([12],[17],[21],[26])$ : the functional dimension, which accounts for changes in the composition of risks and needs covered; the allocation dimension, which looks at the rules for accessing benefits (e.g. if benefits are means-tested or not); the profile of the productive unit delivering services (public, private and third sector); the different mix of economic transactions performed (benefits in cash, benefits in kind or tax breaks with social purposes).

Unfortunately, accurate, relevant and comparable statistics are lacking when focusing on sub-national areas. According to our analysis, the distribution of cash benefits per region (Nuts 2) from NAs represents the only official data currently disseminated on social protection expenditure at the local level. Eusilc individual data permit to estimate cash benefits (plus housing in kind benefits) at sub-national level, but only for large geographical areas.

Finally, it is worth reminding that data sources on social protection receipts and expenditure are not fully homogeneous, because of differences in the boundaries of the social domain (i.e. the distinction between social spending and non-social spending) and in the breakdown of social expenditure among functions $([10],[11])$.

\section{Variables and indicators}

For the purposes of our analysis, we define binary outcome variables which allow us to separate poor from non poor households and a set of predictors relating to the country welfare system. Furthermore, we select/compute a set of variables and indicators to control for the household social and demographic characteristics as well as for the average level of economic wellbeing of the country.

We use both individual (Eusilc data) ${ }^{1}$ and country variables (Esspros, NAs, and Socx). Given lacks of data for some countries, we limit our analysis to a set of countries, namely Austria (AT), Belgium (BE), Germany (DE), Denmark (DK), Spain (ES), Finland (FI), France (FR), Ireland (IE), Italy (IT), Netherlands (NL), Norway (NO), Portugal (PT), Sweden (SE), and United Kingdom (UK). We end with a cross-section data set, including 127324 households for the year 2013.

Table 1 shows a synthetic description of our selection of variables and indicators, also specifying the data sources from which data are taken.

Nowadays, the multidimensional nature of well-being is a worldwide recognized concept, both in academic studies (e.g. [4],[27], [1],[25],[8]) and in official statistics $([16],[20],[19])$. Well-being encompasses several aspects of life (topics or dimensions) such as the availability of economic resources, the level of

\footnotetext{
1 Eurostat, Eusilc, 2013. The responsibility for all conclusions drawn from the data lies entirely with the authors.
} 
education attained, the health status, the quality of interpersonal relations and subjective well-being. Given the overall objective of this study and data constraints, we considered a limited set of well-being indicators, focussing on those aspects of well-being more probably affected by social policies. In particular, we consider two outcome variables, the first (HCR) focuses on monetary poverty, whereas the latter (DEPRIVATION) considers the household inability to make ends meet. In particular the first variable identifies as poor, those households whose equivalised disposable income is below the at-risk-of-poverty threshold $(\mathrm{HCR}=1)$. Following official statistic, the threshold is set at $60 \%$ of the national median equivalised disposable income. This indicator measures low income in comparison to other households in that country, which does not necessarily imply a low standard of living. The second outcome variable identifies as poor (DEPRIVATION=1) those households that report difficulty to make ends meet. This last indicator is included among the deprivation measures published by Eurostat [16]. Thought a significant stream of literature encourages the development of composite indicators of well-being/poverty, ${ }^{2}$ we prefer here to leave separated indicators, to clearly assess if and to what extent each indicator may be affected by the type of welfare system and to avoid confounding due to the nature/procedure of weighting.

To characterize different social protection systems across countries, we propose the following set of indicators: share of social benefits in kind over total benefits (KIND_TOT), share of means-tested benefits over total benefits (MEANS_TOT); share of private social benefits over total social benefits (PRIVATE_TOT), social expenditure per inhabitant as a percentage of GDP (SOC_EXP).

For what concerns decentralization, we identify several indicators. The DECENTR indicator, taken from [18], classifies countries according to the form of the state (whether federalist or unitary) and to the level of delegation of power from central to local governments. Lijphart, in [18], proposes a classification of democracies along a scale from the most federalist and decentralized countries (score 5.0) to the most unitary and centralized ones (1.0). This indicator still represents one of the most influential typology of modern democracies, although this classification has been criticized by many scholars on conceptual, empirical and normative grounds ([24]). This indicator accounts for the level of decentralization in general, whereas our purpose is to measure specifically the territorial decentralization of welfare policies; furthermore, it limits to take constitutional provisions into account, whereas it is also necessary to consider their implementation as performed by decentralised entities $([2])$. To overcome these limits, we propose two supplementary indicators. The first (LOCAL_EXP), defined as the share of social protection expenditures funded by sub-national government, can be viewed as a proxy of the level of autonomy of local governments in delivering social protection; a larger proportion of expenditures funded by lower government levels indicates that fiscal

\footnotetext{
2 A number of methodologies have emerged to assess poverty from a multidimensional perspective. For a review, see [5].
} 
impact is shifted away from central government ([23]). The second indicator (CV_BENEFITS_NUT2) measures the territorial heterogeneity of social benefits received by households. This indicator is computed as the coefficient of variation of per capita social benefits across Nut 2 regions. Higher levels may imply either a higher territorial heterogeneity of the risks or needs to be covered, or a different behaviour of local governments in terms of resources to be devoted to social protection.

Finally, we control for the household social and demographic characteristics which could affect the outcome variables. We selected the following variables or indicators: size of household (HSIZE), Family social-demographic type (FAMTYPE), number of members with tertiary education (NDEGREE), number of members with up to lower secondary education (NLOW), number of female members (NFEM), numbers of members with a job (NWORKERS), number of unemployed members (NUNEMP), number of retired members (NRETIRED), number of old-age members (NOLD), number of kids (NKIDS). Furthermore, for each household, we compute the amount of benefits received (excluding pensions) as a percentage of household average disposable income of the country (BENEFITS). Finally, we use GDP per inhabitant in power purchased parities (GDP_PPP), as a proxy of the value of each country economy.

To give an idea of welfare systems differences, Table 2 shows the country variables values for the year 2013, including the head count ratio and the share of households suffering of deprivation. Greater values of institutional decentralization, not necessarily agrees with higher levels local government expenditure, nor with the territorial heterogeneity of social protection benefits. In the following section, we investigate the relationship between these different measures of decentralization and the risk of being poor or experiencing difficulties to make ends meet, controlling for both welfare states characteristics and households typologies.

\section{Methodology and results}

The objective of our analysis is to contribute to a better understanding of the potential effects of decentralization on monetary poverty as well as on the inability of households to make ends meet. To this end, we model individual binary outcomes (HCR and DEPRIVATION variables) as a function of both family-level and country-level characteristics.

There is a natural hierarchy within the data: there are observations at the family level nested within the country level. This multilevel structure affects model specification and estimation. Possible strategies in quantitative analyses of multi-country datasets include the following: pooling the data for all countries (and using cluster-robust standard errors), using separate models for each country, country fixed effects models, or multilevel models (also known as random effects models or hierarchical models). Multilevel models appear to be the natural choice when one is interested in the country-level predictors or the variance component structure, investigating to what extent unobserved coun- 
try factors affect population units (families). Our dataset contains thousands of observation at the individual level, but the number of countries is small. Recently, Bryan and Jenkins in [9] argued that the small number of countries in most multi-country datasets severely constrains the ability of multilevel regression models to provide robust conclusions about the effects of country-level characteristics on outcomes (see also [7]). Based on this literature, we opted to estimate a pooled logistic regression model (as a generalized linear model with link function logit) using the whole sample and computing cluster robust standard errors to account for the multilevel structure of data ${ }^{3}$.

Table 3 shows our results. Columns (1) and (2) refer to the pooled logistic model for the monetary poverty as dependent variable, while columns (3) and (4) contain results when deprivation is used as outcome variable. To assess which characteristics of welfare states or of the household may represent a risk of poverty, it is enough to look at the significance of coefficients and at their signs. In fact, significant positive coefficients indicate that corresponding variables increase the probability of poverty. Conversely, significant negative signs mean that predictors reduce the risk of poverty. In case of categorical variables, the coefficient sign indicates whether the risk increases or decreases compared to a reference category. The level of institutional decentralization seems to increase the probability of monetary poverty but, at the opposite, it seems to decrease the probability of having difficulties to make ends meet. Higher shares of social protection expenditure held by local governments seem to reduce the probability of incurring in both the kinds of poverty whereas the level of territorial heterogeneity in the distribution of social benefits does not seem to be a significant predictor.

Coming to the characteristics of the welfare systems, we observe how predictors affect differently our dependent variables. Higher shares of means_tested benefits seem to diminish the probability of monetary poverty and increase that of experiencing deprivation. Symmetrically, the presence of kind benefits seem to increase the probability of monetary poverty and reduce the households difficulties to make ends meet. These apparently contradictory results are due to the different nature of well-being aspects measured by the two outcome variables. Social protection systems mainly based on cash benefits (i.e. with lower levels of in kind benefits) affect household disposable income and therefore monetary poverty. Conversely, systems with higher shares of in kind benefits make probably easier to make ends meet since people do not have to pay for some services like health services. In line with this last evidence, we find that cash benefits (the complement of in kind benefits) reduce the probability of monetary poverty but increase the possibility of deprivation. However, the level of country expenditure for social protection significantly reduces both monetary poverty and deprivation whereas the origin of social protection expenditure (whether public or private) does not seem to have any effects.

\footnotetext{
3 It is worth noting that we obtained consistent results applying a multilevel (random intercept) logistic regression. Due to space constraints we decided not to show them in the paper, however they may be required to the authors.
} 
Looking at households typologies, we find that Single parent with dependent children or One-person families are the more vulnerable groups. In particular, the first group has the highest probability of experiencing difficulties to make ends meet whereas the probability of incurring in monetary poverty is not significantly different for the two typologies. The probability of being a poor household increases with the size of the household, the presence of members with a low level of education, the presence of female members (but only for predicting deprivation) and the number of unemployed members. At the opposite it decreases with the number of members with tertiary education, the number of members aged 75 or more, the number of members with a job and the number of retired. The number of kids does not result to be a predictor of the risk of poverty. In particular, we find that the probability of being poor increases with the number of elderly people as far as we do not control for the number of family members with tertiary education and that the number of dependent children ends to be a predictor of poverty, once considered the number of workers of the family.

Finally, it is worth noting that the size of the country economy is a significant predictor of the risk of poverty: higher levels of per inhabitant GDP reduces the probability of poverty.

\section{Final considerations}

This work dealt with the relationship between welfare state typologies - with different degree of decentralization - and the poverty of citizens in European countries. In particular we aimed at investigating how different policy environments and institutions affect outcomes, thus contributing to the policy debate about the role played by decentralization.

For the purposes of our analysis, we used both individual (Eusilc data) and country variables (Esspros, NAs, and Socx). We selected/computed a set of predictors relating to the country welfare system and a set of variables and indicators to control for the household social and demographic characteristics as well as for the average level of economic wellbeing of the country.

We reported the results of a pooled logistic regression analysis for a sample of 127324 households selected in 14 European countries, using two different measures of poverty (monetary poverty and deprivation) as outcome variables.

Estimation outputs point out some interesting evidence. Some of the examined welfare states characteristics seem to affect outputs in the opposite direction. Apparently contradictory results are due to the different nature of well-being aspects measured by the two outcome variables. Social protection systems mainly based on cash benefits (i.e. with lower levels of in kind benefits) affect household disposable income and therefore monetary poverty. Conversely, systems with higher shares of in kind benefits make probably easier to make ends meet since people do not have to pay for some services like health services. 
According to our results, institutional decentralization appears to be a factor risk for monetary poverty and, at the opposite, a protection factor against the risk of deprivation. However a more relevant role of local governments in the funding of social protection expenditure seems to reduce both monetary poverty and deprivation of citizens.

As a direction for future work, we plan to extend the analysis as follows: identify supplementary indicators of decentralization, consider multiple outcomes covering multiple poverty dimensions and use panel data to investigate the dynamic of welfare states evolution. Moreover we are going to devote particular attention to the effects of the recent economic crisis on vulnerable individuals and families, to support specifically-targeted social policies.

\section{References}

1. Aaberge, R., Brandolini, A., Multidimensional poverty and inequality, in: Atkinson, AB and Bourguignon, F. (eds.) Handbook of Income Distribution, vol. 2A, Elsevier, Amster$\operatorname{dam}(2015)$.

2. Addis, P., Coli, A., Pacini, B., Welfare State and Local Government: the Impact of Decentralization on Well-being, 34th IARIW General Conference, Dresden, Germany, August 21-27 (2016).

3. Adema, W., Fron, P. , Ladaique, M., Is the European Welfare State Really More Expensive? Indicators on Social Spending, 1980-2012; and a Manual to the Oecd Social Expenditure Database (Socx), Oecd Social, Employment and Migration Working Papers, No. 124, Oecd Publishing, http://dx.doi.org/10.1787/5kg2d2d4pbf0-en (2011).

4. Anand, S. , Sen, A., Concepts or Human Development and Poverty! A Multidimensional Perspective,United Nations Development Programme, Poverty and human development: Human development papers, pp. 1-20 (1997).

5. Alkire, S., Foster, J.E., Seth, S., Roche, J.M., Santos, M. E., Multidimensional poverty measurement and analysis, Oxford University Press (2015).

6. Andreotti A., Mingione, E. Polizzi, E., Local welfare systems: A Challenge For Social Cohesion, Urban studies, vol. 49, n. 9, pp. 1925-1940 (2012).

7. Austin, P.C., Estimating Multilevel Logistic Regression Models When the Number of Clusters is Low: A Comparison of Different Statistical Software Procedures, International Journal of Biostatistics, vol. 6, n. 1, doi: 10.2202/1557-4679.1195 (2010).

8. Betti, G., Gagliardi, F., Lemmi, A., Verma, V. , Comparative measures of multidimensional deprivationin the European Union, Empirical Economics, 49(3), pp. 1071-1100 (2015).

9. Bryan, M. L. , Jenkins, S.P., Multilevel Modelling of Country Effects: A Cautionary Tale, Eur Sociol Rev, doi: 10.1093/esr/jcv059 (2015).

10. Coli A., Micheletti, E., Pacini, B., European welfare state in times of crisis according to macroeconomic official statistics, Proceeding of the 48th scientific meeting of the Italian Statistical Society (2016).

11. Coli, A., Valentini, A., Mapping Social Protection Statistics, in: Policies, Welfare and Financial Resources, the Impact of the Crisis on Territories, Pisa University Press (2017).

12. Esping-Andersen, G., The three worlds of welfare capitalism, Polity Press (1990).

13. Eurostat, The European System of European System of Integrated Social Protection Statistics, Manual (2011).

14. Eurostat, European System of Accounts (ESA 2010), Manual (2013).

15. Eurostat, NUTS Nomenclature of Territorial Units for Statistic, by regional level (2013).

16. Eurostat, Material deprivation statistics - early results, Statistics explained, http:ec.europa.eueurostatstatistics-explainedindex.phpMaterial_deprivation_statistics early_results \#Making_ends_meet 
17. Ferrera, M., Fargion, V., Jessoula, M., Alle radici del Welfare all'italiana Origini e futuro di un modello sociale squilibrato, Saggi e ricerche, collana storica della banca dItalia, Marsilio (2012).

18. Lijphart A., Patterns of Democracy. Government Forms and Performance in Thirty-Six Countries, New Haven/London (1999).

19. ISTAT, www.istat.ititbenessere-e-sostenibilitá (August 2017)

20. OECD, www.oecdbetterlifeindex.org (August 2017)

21. Powel, M., Boyne, G., The spatial strategy of equality and the spatial division of welfare, Social policy and administration, vol. 33 n. 2 (2001).

22. Rodriguez-Pose, A., Ezcurra, R., Does decentralization matter for regional disparities?

A cross-country analysis, Journal of Economic Geography, Oxford University Press (2009)

23. Schneider, A., Decentralization: Conceptualization and Measurement, Studies in Comparative International Development, vol. 38, n. 3, pp. 32-56 (2003).

24. Sellers, J. M., Lidstrm, A., Decentralization, Local Government and the Welfare State, Governance, Wiley Online Library (2007).

25. Stiglitz Commission, Report on the measurement of economic performance and social progress, www.stiglitz-sen-fitoussi.fr (2009)

26. Titmuss, R.. Social policy, An introduction, Allen\&Unwin (1974).

27. Whelan, C.T., Nolan, B., Maitre, B., Multidimensional poverty measurement in Europe: An application of the adjusted headcount approach, Journal of European Social Policy, vol. 24, n. 2,pp. 183-197, SAGE Publications, Sage UK (2014). 
Table 1 Variables and indicators description.

\begin{tabular}{|c|c|c|c|}
\hline Name & Description & Categories & Data source \\
\hline HCR & Monetary poverty & $\begin{array}{l}0=\text { above poverty thresh- } \\
\text { old } \\
1=\text { under poverty thresh- } \\
\text { old }\end{array}$ & Eusilc \\
\hline DEPRIVATION & $\begin{array}{l}\text { Being or not able to } \\
\text { make ends meet }\end{array}$ & $\begin{array}{l}0=\text { with some difficulties, } \\
\text { relatively easily, easily, } \\
\text { quite easily } \\
1=\text { with great difficulties, } \\
\text { with difficulties }\end{array}$ & Eusilc \\
\hline KIND_TOT & $\begin{array}{l}\text { Share of in kind benefits } \\
\text { over total benefits }\end{array}$ & percentage values & Esspros \\
\hline MEANS_TOT & $\begin{array}{l}\text { Share of means-tested } \\
\text { benefits over total bene- } \\
\text { fits }\end{array}$ & percentage values & Esspros \\
\hline PRIVATE_TOT & $\begin{array}{l}\text { Share of private social } \\
\text { benefits over total social } \\
\text { benefits, } 2011\end{array}$ & percentage values & Soxc \\
\hline SOC_EXP & $\begin{array}{l}\text { Social expenditure per } \\
\text { inhabitant as a percent- } \\
\text { age of GDP }\end{array}$ & percentage values & Soxc \\
\hline DECENTR & $\begin{array}{l}\text { Decentralization mea- } \\
\text { sure based on the legal } \\
\text { system of the country }\end{array}$ & $\begin{array}{l}\text { 5-point scale from the } \\
\text { most federalist and } \\
\text { decentralized countries } \\
\text { (score 5) to the most } \\
\text { unitary and centralized } \\
\text { ones (1) }\end{array}$ & Ljiphart 1999 \\
\hline LOCAL_EXP & $\begin{array}{l}\text { Share of general govern- } \\
\text { ment expenditure for so- } \\
\text { cial protection paid by } \\
\text { lower levels of govern- } \\
\text { ment }\end{array}$ & percentage values & Esspros \\
\hline CV_BEN_NUTS2 & $\begin{array}{l}\text { Variation coefficient of } \\
\text { per capita social benefits } \\
\text { across regions (NUTS } \\
\text { 2)- } 2011\end{array}$ & percentage values & Eurostat,NAs \\
\hline HSIZE & Numbers of members & Number & Eusilc \\
\hline FAMTYPE & Type of household & $\begin{array}{l}1=\text { one person household } \\
2=\text { households without } \\
\text { dependent children } \\
3=\text { single parent with } \\
\text { dependent children } \\
4=\text { households with de- } \\
\text { pendent children } \\
5=\text { other households }\end{array}$ & Eusilc \\
\hline NDEGREE & $\begin{array}{l}\text { Number of members } \\
\text { with tertiary education }\end{array}$ & Number & Eusilc \\
\hline NLOW & $\begin{array}{l}\text { Number of members } \\
\text { with up to lower sec- } \\
\text { ondary education }\end{array}$ & Number & Eusilc \\
\hline NFEM & $\begin{array}{l}\text { Number of female mem- } \\
\text { bers }\end{array}$ & Number & Eusilc \\
\hline NWORKERS & $\begin{array}{l}\text { Numbers of members } \\
\text { with a job }\end{array}$ & Number & Eusilc \\
\hline NUNEMP & $\begin{array}{l}\text { Numbers of unemployed } \\
\text { members }\end{array}$ & Number & Eusilc \\
\hline NOLD & $\begin{array}{l}\text { Number of members } \\
\text { aged } 75 \text { or more }\end{array}$ & Number & Eusilc \\
\hline NKIDS & $\begin{array}{l}\text { Number of members } \\
\text { aged less than } 16\end{array}$ & Number & Eusilc \\
\hline BENEFITS & $\begin{array}{l}\text { Benefits received (old } \\
\text { age and survivors' bene- } \\
\text { fits excluded) as a quota } \\
\text { of households' average } \\
\text { disposable income }\end{array}$ & Number & Eusilc \\
\hline GDP_PPP & $\begin{array}{l}\text { GDP per inhabitant in } \\
\text { power purchased parities }\end{array}$ & PPP & Eurostat, NAs \\
\hline
\end{tabular}


Table 2 Country variables values for the year 2013

\begin{tabular}{|c|c|c|c|c|c|}
\hline COUNTRY & $\mathrm{HCR}$ & DEPRIVATION & KIND_TOT & MEANS_TOT & PRIVATE_TOT \\
\hline AT & 15.78 & 14.55 & 30.22 & 8.35 & 6.80 \\
\hline $\mathrm{BE}$ & 17.18 & 21.98 & 31.81 & 5.16 & 6.50 \\
\hline DE & 20.33 & 10.40 & 37.60 & 12.09 & 11.10 \\
\hline DK & 16.19 & 12.22 & 40.07 & 35.91 & 14.50 \\
\hline $\mathrm{ES}$ & 18.87 & 36.75 & 30.52 & 14.45 & 1.90 \\
\hline FI & 16.62 & 7.55 & 38.35 & 5.34 & 4.10 \\
\hline FR & 14.02 & 19.86 & 36.33 & 11.51 & 10.30 \\
\hline IE & 15.57 & 34.61 & 37.28 & 31.47 & 7.90 \\
\hline IT & 19.25 & 39.94 & 24.61 & 5.69 & 7.50 \\
\hline NL & 11.99 & 16.59 & 35.36 & 13.44 & 24.10 \\
\hline $\mathrm{NO}$ & 14.24 & 7.34 & 41.46 & 4.23 & 9.00 \\
\hline $\mathrm{PT}$ & 18.27 & 46.08 & 26.50 & 8.37 & 7.20 \\
\hline $\mathrm{SE}$ & 18.97 & 6.88 & 45.55 & 2.66 & 10.50 \\
\hline UK & 17.15 & 19.68 & 38.33 & 13.64 & 21.50 \\
\hline COUNTRY & SOC_EXP & GDP_PPP & DECENTR & LOCAL_EXP & CV_BEN_NUTS2 \\
\hline AT & 0.30 & 35000 & 4.50 & 22.31 & 7.16 \\
\hline $\mathrm{BE}$ & 0.30 & 32000 & 3.20 & 11.91 & 9.24 \\
\hline $\mathrm{DE}$ & 0.30 & 33200 & 5.00 & 27.31 & 8.33 \\
\hline DK & 0.32 & 33700 & 2.00 & 32.14 & 4.15 \\
\hline ES & 0.25 & 24300 & 3.00 & 39.35 & 16.52 \\
\hline FI & 0.31 & 30200 & 2.00 & 31.15 & 3.12 \\
\hline FR & 0.35 & 28900 & 1.30 & 8.78 & 7.55 \\
\hline IE & 0.20 & 35300 & 1.00 & 1.73 & 0.10 \\
\hline IT & 0.29 & 26200 & 1.50 & 19.64 & 13.55 \\
\hline NL & 0.30 & 35500 & 3.00 & 13.22 & 7.16 \\
\hline $\mathrm{NO}$ & 0.23 & 49300 & 2.00 & 24.66 & 5.49 \\
\hline $\mathrm{PT}$ & 0.27 & 20600 & 1.00 & 1.28 & 17.08 \\
\hline SE & 0.29 & 33300 & 2.00 & 44.28 & 4.27 \\
\hline UK & 0.27 & 29000 & 1.00 & 5.78 & 8.99 \\
\hline
\end{tabular}


Table 3 Logit model with standard errors and cluster adjusted standard errors

\begin{tabular}{|c|c|c|c|c|}
\hline & \multicolumn{4}{|c|}{ Dependent variable: } \\
\hline & \multicolumn{2}{|c|}{ HCR } & \multicolumn{2}{|c|}{ DEPRIVATION } \\
\hline & Coefficient & Std. Error & Coefficient & Std Error \\
\hline DECENTR & $0.176^{* * *}$ & $(0.057)$ & $-0.065^{*}$ & $(0.035)$ \\
\hline LOCAL_EXP & $-0.015^{* *}$ & $(0.007)$ & $-0.019^{* * *}$ & $(0.007)$ \\
\hline CV_BEN_NUTS2 & -0.010 & $(0.023)$ & 0.050 & $(0.030)$ \\
\hline SOC_EXP & $-3.233^{* *}$ & $(1.623)$ & $-3.577^{*}$ & $(1.961)$ \\
\hline GDP_PPP & $-0.00005^{* * *}$ & $(0.00001)$ & -0.00003 & $(0.00002)$ \\
\hline KIND_TOT & $0.051^{* *}$ & $(0.024)$ & $-0.053^{* * *}$ & $(0.011)$ \\
\hline MEANS_TOT & $-0.026^{* * *}$ & $(0.009)$ & $0.022^{* *}$ & $(0.011)$ \\
\hline PRIVATE_TOT & -0.011 & $(0.026)$ & -0.013 & $(0.009)$ \\
\hline HSIZE & $0.390^{* * *}$ & $(0.047)$ & $0.136^{* * *}$ & $(0.035)$ \\
\hline NDEGREE & $-0.586^{* * *}$ & $(0.059)$ & $-0.511^{* * *}$ & $(0.051)$ \\
\hline NLOW & $0.210^{* * *}$ & $(0.053)$ & $0.233^{* * *}$ & $(0.069)$ \\
\hline FAMTYPE2 & $-0.670^{* * *}$ & $(0.155)$ & $-0.389^{* * *}$ & $(0.088)$ \\
\hline FAMTYPE3 & -0.126 & $(0.115)$ & $0.372^{* * *}$ & $(0.067)$ \\
\hline FAMTYPE4 & $-0.565^{* * *}$ & $(0.146)$ & $-0.279^{* * *}$ & $(0.079)$ \\
\hline FAMTYPE5 & $-0.906^{* * *}$ & $(0.319)$ & $-0.632^{* * *}$ & $(0.202)$ \\
\hline NFEM & 0.035 & $(0.032)$ & $0.102^{* * *}$ & $(0.020)$ \\
\hline NOLD & $-0.214^{* *}$ & $(0.090)$ & $-0.174^{* * *}$ & $(0.067)$ \\
\hline NKIDS & -0.051 & $(0.054)$ & -0.009 & $(0.031)$ \\
\hline NWORKERS & $-1.420^{* * *}$ & $(0.100)$ & $-0.546^{* * *}$ & $(0.040)$ \\
\hline NUNEMP & $0.424^{* * *}$ & $(0.086)$ & $0.589^{* * *}$ & $(0.059)$ \\
\hline NRETIRED & $-0.999^{* * *}$ & $(0.162)$ & $-0.578^{* * *}$ & $(0.065)$ \\
\hline BENEFITS & $-1.446^{* * *}$ & $(0.350)$ & $0.690^{* * *}$ & $(0.195)$ \\
\hline Constant & 0.432 & $(0.952)$ & $2.546^{*}$ & $(1.300)$ \\
\hline Observations & 127,324 & 126,981 & & \\
\hline Log Likelihood & $-43,007.030$ & $-51,720.610$ & & \\
\hline Akaike Inf. Crit. & $86,060.070$ & $103,487.200$ & & \\
\hline
\end{tabular}

